\title{
KAJIAN PENINGKATAN PENDAPATAN PENGRAJIN GULA KELAPA DI DESA PURBOSARI KECAMATAN SELUMA BARAT KABUPATEN SELUMA
}

\author{
Study Of The Income Increasing Of Coconut Sugar Producers In \\ Purbosari Village Western Seluma District Seluma Regency \\ Sriyoto, dan Bambang Sumantri \\ Jurusan Sosial Ekonomi Pertanian Fakultas Pertanian Universitas Bengkulu
}

\begin{abstract}
Coconut sugar is one commodity that has potential importance in the composition of the food in the community. Viewed in terms of quality, the quality of the products are still not equal among the producers. This causes the bargaining position of producers becomes weak and coconut sugar prices tend to be low. Seluma Regency especially Western Seluma District has fertile lowland areas and is one of the main producers of coconut sugar precisely in Purbosari village. This study aimed to determine the income level and income-raising efforts of coconut sugar producers in the Purbosari village, Western Seluma District, Seluma Regency. Location of the study was set intentionally (purposive). Data taken in this study were derived from the primary data (interviews) and secondary data (through literature). This study used survey method and the method of selecting the sample in this study was calculated using census. The data analysis used in this study were a quantitative and qualitative analysis. Quantitative analysis was used to calculate the income of coconut sugar producers and qualitative analysis conducted through a descriptive approach. Based on the research discovered that the average income of coconut sugar producers was Rp715.569,60 per week / 40 trees. Common difficulties faced by coconut sugar producers were capital, production engineering, business management and marketing network. Seluma local governments can play a role in efforts to increase the income of coconut sugar producers by providing them with capital, appropriate technology, improved knowledge of entrepreneurship and innovation, as well as business management assistance.
\end{abstract}

Keywords: income, coconut sugar, producer.

\section{PENDAHULUAN}

Pembangunan pada hakikatnya merupakan serangkaian usaha dan kebijakan untuk meningkatkan kesejahteraan masyarakat dan pengentasan kemiskinan. Pembangunan suatu wilayah dapat dicapai dengan 
memberdayakan potensi sumber daya yang ada, sehingga mampu memberikan nilai positif ekonomi daerah tersebut (Sofiani, 2015). Peran sektor pertanian dalam pembangunan ekonomi sangat penting karena sebagian besar masyarakat di negara berkembang menggantungkan hidupnya pada sektor pertanian.

Gula kelapa merupakan salah satu komoditas yang memiliki potensi penting dalam komposisi bahan pangan di masyarakat (konsumen) dan sebagai bahan baku dalam industri makanan. Oleh karena itu, gula kelapa memiliki nilai ekonomi yang cukup tinggi sehingga menarik bagi banyak kalangan untuk terjun dan menekuni bisnis di bidang ini. Dengan memiliki nilai ekonomi yang tinggi dan strategis, gula kelapa belum memberikan keuntungan bagi para produsen atau pengrajin gula kelapa (Purwaningsih, Sriningsih, dan Rosyad, 2005).

Gula kelapa pada umumnya diusahakan secara tradisional oleh para pengrajin dengan menggunakan peralatan dan pengolahan secara sederhana. Usaha gula kelapa pada umumnya merupakan usaha industri kecil atau rumah tangga. Pengolahan gula kelapa sejak dari pengambilan nira sampai dengan pemasakan dan pencetakan menghabiskan waktu dari pagi hingga sore atau memerlukan waktu delapan hingga sepuluh jam.

Dilihat dari segi kualitas gula kelapa ternyata kualitas hasil produksi mereka masih belum sama di antara para pengrajin. Bahkan seorang pengrajin gula kelapa tidak menghasilkan produk gula kelapa yang sama kualitasnya antara produksi suatu hari dengan produk hari berikutnya. Kondisi ini menyebabkan para pengrajin gula kelapa menjadi bulan-bulanan pedagang pengumpul, sehingga menjadikan posisi tawar pengrajin menjadi lemah. Akibatnya yang dirasakan langsung oleh pengrajin gula kelapa adalah rendahnya harga gula kelapa. Di lain pihak pedagang pengumpul banyak mendapatkan keuntungan dari hasil penjualan gula kelapa, sehingga kondisi sosial ekonomi para pengrajin gula kelapa dari waktu ke waktu tidak mengalami perubahan atau dengan kata lain kehidupan para pengrajin gula kelapa belum menunjukkan adanya peningkatan (Supomo, 2007).

Kabupaten Seluma khususnya Kecamatan Seluma Barat merupakan daerah dataran rendah yang subur dan merupakan salah satu penghasil gula kelapa tepatnya di Desa Purbosari. Banyaknya pengrajin gula kelapa di daerah tersebut karena berkembangnya perkebunan kelapa rakyat. Berangkat dari penjelasan tersebut, penelitian ini bertujuan untuk mengetahui tingkat pendapatan dan upaya peningkatan pendapatan pengrajin gula kelapa di Desa Purbosari Kecamatan Seluma Barat Kabupaten Seluma.

\section{METODE PENELITIAN}

Penelitian ini dilakukan di Desa Purbosari, Kecamatan Seluma Barat, Kabupaten Seluma. Lokasi penelitian ditetapkan secara sengaja (purposive), 
dengan pertimbangan bahwa wilayah tersebut merupakan salah satu sentra pengolahan gula kelapa di Kecamatan Seluma Barat dan merupakan salah satu penghasil gula kelapa dalam skala industri rumah tangga.

Data yang diambil dalam penelitian ini yaitu bersumber dari data primer dan data sekunder. Data primer merupakan data yang diperoleh melalui wawancara langsung dengan pengrajin gula kelapa atau melakukan teknik wawancara yang mendalam (depth interview) dengan menggunakan kuesioner atau daftar pertanyaan yang dipersiapkan. Wawancara yang mendalam dimaksudkan untuk mendapatkan data secara detail khususnya data yang berhubungan dengan produksi, harga, biaya-biaya, ketersediaan bahan baku dan penolong, penggunaan teknologi dan peralatan, kualitas produk, dan modal. Data sekunder yaitu data yang diperoleh dari literatur baik buku maupun jurnal atau hasil penelitian terdahulu yang digunakan sebagai pelengkap. Selain itu data sekunder juga dapat diperoleh dari berbagai instansi pemerintah yang ada kaitannya dengan penelitian.

Penelitian ini menggunakan metode survei. Metode ini adalah suatu penelitian di mana informasi didapat secara langsung dari sekelompok individu dalam populasi (Baily, 1987 dan Dane, 1990). Dalam metode survei, data dikumpulkan dan hubungan antara peubah diselidiki untuk memberikan gambaran terhadap obyek penelitian (Sanyoto, 2011).

Metode pemilihan sampel dalam penelitian ini dilakukan dengan menggunakan metode sensus yaitu seluruh populasi dijadikan sebagai sampel, yakni pengrajin gula kelapa di Desa Purbosari, Kecamatan Seluma Barat, Kabupaten Seluma.

\section{Metode Analisis Data}

Analisis data yang digunakan dalam penelitian ini adalah analisis kuantitatif dan kualitatif. Analisis kuantitatif digunakan untuk menghitung pendapatan pengrajin gula kelapa dan analisis kualitatif dilakukan melalui pendekatan deskriptif.

\section{Analisis Pendapatan dan Upaya Peningkatannya}

Untuk mengetahui tingkat pendapatan pengrajin gula kelapa dihitung dengan langkah-langkah perhitungan menurut Soekartawi (1995) dengan formulasi:

$$
\mathrm{Pd}=\mathrm{TR}-\mathrm{TC}
$$

dimana: Pd adalah pendapatan pengrajin gula kelapa ( $\mathrm{Rp} / \mathrm{minggu}), \mathrm{TR}$ adalah penerimaan total pengrajin gula kelapa ( $\mathrm{Rp} / \mathrm{minggu})$, dan TC adalah biaya total pengrajin gula kelapa ( $\mathrm{Rp} / \mathrm{minggu})$

Untuk menganalisis upaya peningkatan pendapatan pengrajin gula kelapa digunakan analisis deskriptif. Dalam analisis deskriptif, sebaran data yang 
diperoleh disajikan melalui proses kodetifikasi, kategorisasi, interpretasi, pemaknaan, dan abstraksi (Meleong, 2004 dan Sukandarumidi, 2004). Analisis deskriptif dimaksudkan membuat penyandaraan/pemeriaan secara sistematis, faktual, dan akurat mengenai fakta-fakta dan sifat-sifat populasi tertentu (Usman dan Akbar, 1995, dan Suryabrata, 1998). Dengan analisis deskriptif ini akan diperoleh gambaran tentang sesuatu yang lazim atau unik dalam suatu masyarakat serta gambaran tentang variasi-variasi yang ada dalam masyarakat, khususnya yang berkaitan dengan obyek dan subyek dari penelitian.

\section{HASIL DAN PEMBAHASAN}

\section{Karakteristik Pengrajin Gula Kelapa}

Berdasarkan hasil penelitian, umur pengrajin gula kelapa di lokasi penelitian bervariasi yaitu berkisar antara 28-64 tahun, dengan rata-rata 41,52 tahun. Mubyarto (1989) menyatakan bahwa petani yang berada pada usia produktif akan memberikan hasil kerja yang maksimal, dibanding usia tidak produktif. Seperti halnya umur pengrajin gula kelapa berada pada kondisi usia produktif sehingga diharapkan akan berpengaruh terhadap produktivitas kerja dan peningkatan produksi. Tentu hal ini juga akan dibarengi dengan lamanya pengalaman dalam usaha pengolahan gula kelapa.

Tingkat pendidikan merupakan salah satu penunjang keberhasilan dalam menjalankan usaha sebagai pengrajin gula kelapa. Tingkat pendidikan seseorang akan mempengaruhi pola pikir dalam mengelola usahanya. Semakin tinggi pendidikan seseorang, maka akan semakin luas wawasan dan semakin membuka diri terhadap kemajuan teknologi. Hasil penelitian menunjukkan tingkat pendidikan pengrajin gula kelapa persentase sebesar $64,51 \%$. Hal ini mengindikasikan bahwa tingkat pendidikan yang dimiliki oleh pengrajin gula kelapa masih tergolong rendah. Kondisi tingkat pendidikan ini hendaknya diimbangi dengan penambahan pengetahuan mengenai penyuluhan cara pengolahan gula kelapa yang baik atau diperlukan sekolah lapang sehingga diharapkan pengrajin gula kelapa dapat meningkatkan produksi dan pendapatan usahanya.

Tanggungan keluarga adalah semua jiwa yang tinggal bersama kepala keluarga dan seluruh kebutuhan hidupnya dibiayai oleh kepala keluarga. Data penelitian menunjukkan bahwa jumlah tanggungan keluarga pengrajin gula kelapa adalah 3-4 jiwa dengan persentase sebesar 41,80\%. Besarnya jumlah tanggungan keluarga akan mempengaruhi pengeluaran atau konsumsi pengrajin gula kelapa, semakin besar jumlah tanggungan keluarga akan semakin besar pengeluaran konsumsi rumah tangga. Dengan kondisi ini pengrajin gula kelapa cenderung mengurangi penggunaan tenaga kerja luar keluarga untuk kegiatan usahanya, sehingga pendapatan yang diperoleh akan semakin besar.

40 | Sriyoto dan Bambang Sumantri, Kajian Peningkatan Pendapatan ... 
Rata-rata jumlah kepemilikan pohon kelapa yang dikelola oleh pengrajin di daerah penelitian sebanyak 40 batang dengan produksi gula kelapa sebesar $169,09 \mathrm{~kg} / \mathrm{minggu}$. Menurut pengakuanpengrajin kualitas gula kelapa hasil produksi masih kurang baik, dan kualitas gula kelapa sesama pengrajin belum seragam.

Data penelitian menunjukkan bahwa di lokasi penelitian pengrajin gula kelapa pada umumnya dalam melakukan usahanya masih sederhana yaitu dengan penggunaan peralatan yang sederhana atau penggunaan teknologi yang sederhana. Keterampilan/skill yang dimiliki oleh para pengrajin masih tergolong relatif rendah. Lebih lanjut, Kepemilikan modal usaha oleh pengrajin gula kelapa di daerah penelitian masih tergolong rendah yaitu rata-rata sebesar 2 juta rupiah.

\section{Biaya, Penerimaan, dan Pendapatan Pengrajin Gula Kelapa}

Total biaya merupakan seluruh biaya yang dikeluarkan oleh pengrajin gula kelapa yaitu terdiri dari biaya variabel dan tetap. Penggunaan biaya variabel dalam pengolahan gula kelapa seperti: biaya bahan baku, kayu bakar, minyak tanah, kapur, dan tenaga kerja dari luar keluarga. Penggunaan biaya tetap dalam pengolahan gula kelapa seperti biaya penyusutan alat dan semua pohon. Penerimaan dapat diketahui dengan cara mengalikan antara jumlah produksi gula kelapa dengan harga yang diterima oleh pengrajin gula kelapa. Pendapatan adalah selisih antara penerimaan dengan total biaya dikeluarkan oleh pengrajin gula kelapa. Menurut Mubyarto (1989) pendapatan adalah selisih antara penerimaan dan semua biaya yang dikeluarkan menyangkut proses produksi. Rincian tentang rata-rata biaya, penerimaan, dan pendapatan pengrajin gula kelapa dapat disajikan pada Tabel 1.

Tabel 1. Rata-Rata Biaya, Penerimaan, dan Pendapatan Pengrajin Gula Kelapa di Desa Purbosari per Minggu/40 Batang

\begin{tabular}{llr}
\hline No. & \multicolumn{1}{c}{ Uraian } & Jumlah (Rp) \\
\hline 1. & Biaya total: & \\
& a. Biaya variabel & $655.646,78$ \\
& b. Biaya tetap & $436.695,28$ \\
2. Penerimaan & $1.371 .216,33$ \\
3. & Pendapatan & $715.569,60$ \\
\hline
\end{tabular}

Sumber: Data primer diolah, 2016

Berdasarkan Tabel 1 diketahui rata-rata pendapatan pengrajin gula kelapa sebesar Rp715.569,60 per minggu/40 batang dengan kata lain bahwa besarnya pendapatan yang diperoleh pengrajin gula kelapa satu bulan sebesar Rp2.862.278,4. Penelitian Sofiani (2015) tentang analisis pendapatan dan pola pemasaran gula kelapa di Desa Semedo Kecamatan Pekuncen Kabupaten 
Banyumas menunjukkan bahwa besarnya pendapatan pengrajin gula kelapa sebesar Rp2.267.884,00 per bulan. Pendapatan ini lebih kecil dibanding dengan hasil penelitian di Desa Purbosari. Hal ini disebabkan karena perbedaan harga jual gula kelapa yaitu di Desa Purbosari dengan harga jual sebesar Rp $8.109,68 / \mathrm{kg}$.

\section{Upaya Peningkatan Pendapatan Pengrajin Gula Kelapa}

Dengan diberlakukannya Undang-undang Otonomi Daerah, maka secara otomatis sistem pembangunan nasional lebih mengutamakan pada sistem pembangunan wilayah. Pemerintah daerah merupakan pondasi bagi proses desentralisasi di masa depan, di mana dalam Undang-undang tersebut pemerintah daerah diberikan kewenangan yang lebih besar. Dengan demikian diharapkan pemerintah daerah mampu membangun wilayahnya masingmasing sesuai dengan kondisi dan potensi unggulan daerahnya.

Otonomi daerah pada hakikatnya merupakan rangkaian upaya pembangunan daerah dalam rangka tercapainya tujuan pembangunan nasional. Otonomi daerah juga mempunyai makna strategis yaitu mendorong proses pengambilan keputusan yang lebih cepat, tepat dan mengutamakan kondisi wilayah. Oleh karena itu keberhasilan pembangunan wilayah dengan otonomi daerah tidak terlepas dari kemampuan aparatur pemerintah, kelembagaan, dan sumber daya manusia (Supomo, 2007).

Dalam upaya penguatan struktur ekonomi pertanian tradisional, usaha gula kelapa merupakan salah satu usaha yang memiliki potensi penting untuk dikembangkan di Kabupaten Seluma sehingga merupakan unggulan daerah. Dalam hal ini ukuran unggulan daerah terutama dilihat dari aspek sumber daya alam, sumber daya manusia, lokasi strategis, potensi pengaruh ke depan/ ke belakang dari industri besar, serta peran pemerintah dalam mengembangkan wilayahnya baik penyediaan infrastruktur, fasilitas sosial, maupun pengembangan produk unggulan daerah melalui pembinaan industri/usaha kecil menengah.

Data penelitian menunjukkan bahwa rata-rata pengrajin gula kelapa di Desa purbosari menghasilkan produksi dan kualitas yang masih rendah, keterbatasan mengakses pasar atau kurang mampu menguasai jaringan pemasaran gula kelapa sehingga pengrajin menjadi lemah dalam posisi tawar dengan pedagang pengumpul. Dengan lemahnya posisi tawar ini, akibat yang dirasakan langsung oleh para pengrajin gula kelapa adalah rendahnya harga gula kelapa. Dengan demikian pada akhirnya pengrajin gula kelapa akan memperoleh pendapatan yang rendah. Hal ini sebagai akibat dari pengetahuan atau pendidikan yang dimiliki oleh para pengrajin gula kelapa pada umumnya masih rendah, teknologi pengolahan dan penggunaan alat-alat yang sederhana/tradisional. 
Kemampuan manajerial pengrajin gula kelapa seperti pengambilan keputusan, penyusunan perencanaan, evaluasi, komunikasi dalam usaha pengolahan gula kelapa nampak belum dimiliki oleh pengrajin gula kelapa. Di samping itu para pengrajin belum memiliki jiwa kewirausahaan sehingga tidak timbul pemikiran untuk meningkatkan kualitas produk, dan memperluas penjualan gula kelapa.

Kondisi kehidupan pengrajin gula kelapa sangat memprihatinkan. Mereka sulit melepaskan diri dari jeratan ijon tengkulak/pedagang/ pada hubungan antara pengrajin dengan pengumpul yang semula bersifat kekeluargaan sudah mulai menjurus ke bisnis semata. Akibatnya para pengrajin gula kelapa pada umumnya tidak ada kesempatan untuk memupuk modal atau tabungan.

Oleh karena itu apabila pemerintah daerah Kabupaten Seluma akan meningkatkan industri kecil gula kelapa dan berupaya meningkatkan pendapatan pengrajin, serta sebagai program unggulan, maka pemerintah daerah seyogyanya memberi bantuan fisik dan non fisik bagi pengrajin gula kelapa. Bantuan fisik seperti bantuan modal untuk operasi dan pengadaan alat/mesin untuk pencetakan gula kelapa sehingga produksi seragam dan kualitas produksinya dapat stabil. Bantuan non fisik ini berupa pelatihanpelatihan, penyuluhan, pengenalan teknologi tepat guna, studi banding, pengembangan jiwa kewirausahaan dan inovasi bagi para pengrajin gula kelapa dengan tujuan untuk mengembangkan motivasi berprestasi. Kegiatan ini ditujukan untuk merubah sikap mental yang tradisional menjadi sikap mental wirausahawan sukses yang mampu memanfaatkan segala peluang, menumbuhkan kemampuan untuk berkomunikasi dengan orang lain, menumbuhkan kreativitas tinggi, mempunyai keuletan dan kemauan keras untuk maju agar usahanya lebih berkembang.

\section{SIMPULAN DAN SARAN}

\section{Simpulan}

1. Pendapatan pengrajin gula kelapa di daerah penelitian sebesar Rp715.569,60 per minggu/40 batang.

2. Kesulitan umum yang dihadapi pengrajin gula kelapa adalah permodalan, teknik produksi, manajemen usaha dan jaringan pemasaran. Semua kesulitan dimaksud merupakan akumulasi dari mental para pengrain gula kelapa yang masih tradisional, kurang kreatif dan inovatif dalam bisnis dan terjerat ijon oleh pedagang pengumpul.

\section{Saran}

1. Masih perlunya peran pemerintah daerah Seluma dalam upaya peningkatan pendapatan pengrajin gula kelapa yaitu pemberian bantuan modal, 
teknologi tepat guna, peningkatan pengetahuan jiwa kewirausahaan dan inovasi, serta bantuan manajemen usaha.

2. Perlunya pembinaan dan pengembangan usaha kelompok pengrajin gula kelapa secara berkelanjutan dan berkesinambungan.

\section{DAFTAR PUSTAKA}

Baily, K.D. 1987. Methods of Social Research. Third Edition. New York. The Free Press.

Dane, F.C. 1990. Research Methods. California: Books and Cole Publishing Company.

Meleong, L.J. 2004. Metodologi Penelitian Kualitatif. Edisi I cet. ke-18. Bandung: PT Remaja Rosdakarya.

Mubyarto. 1989. Pengantar Ekonomi Pertanian. LPES. Jakarta.

Purwaningsih, A., E. Sriningsih, dan A. Rosyad. 2005. Peranan Kelompok Usaha Bersama dalam Perbaikan Posisi Tawar dan Pendapatan Pengrajin Gula Kelapa di Kabupaten Banyumas. Jurnal Pembangunan Pedesaan Vol.5 No. 2. Agustus 2005: 86-90. ISSN 1411-9250.

Soekartawi. 1995. Analisis Usaha Tani. Jakarta: UI Press.

Sofiani, Venita. 2015. Analisis Pendapatan dan Pola Pemasaran Petani Gula Kelapa di Desa Semedo Kecamatan Pekuncen Kabupaten Banyumas. Seminar Nasional 26 September 2015.

Sukandarumidi. 2004. Metodologi Penelitian. Petunjuk Praktis untuk Peneliti Pemula. Cet. ke-2. Yogyakarta: UGM Press.

Sunyoto, D. 2011. Statistik Deskriptif untuk Ekonomi. Bandung: CV Yramawidya.

Supomo. 2007. Meningkatkan Kesejahteraan Pengrajin Gula Kelapa di Wilayah Kabupaten Purbalingga. Jurnal Ekonomi Pembanguna Vol. 12 No. 2. Agustus 2007: 149-162.

Suryabrata, S. 1998. Metodologi Penelitian. Jakarta: Rajawali Press.

Usman, H. dan P.S. Akbar. 1995. Metodologi Penelitian Sosial. Bandung: Bumi Aksara.

44 | Sriyoto dan Bambang Sumantri, Kajian Peningkatan Pendapatan ... 